\title{
POLA PENDIDIKAN DAN POLA DAKWAH ISLAMIC CENTRE MU'ADZ BIN JABAL (ICM) DI KOTA KENDARI
}

\author{
Asliah Zainal $^{1)}$; Sudarmi Suud ${ }^{2)}$; Muh. Asrianto Zainal ${ }^{3)}$ \\ ${ }^{1)}$ Fakultas Ushuluddin, Adab, dan Dakwah Institut Agama Islam Negeri \\ Kendari; ${ }^{2)}$ Fakultas Keguruan dan Ilmu Pendidikan Universitas \\ Haluole Kendari; ${ }^{3}$ Fakultas Syari'ah Institut Agama Islam Negeri \\ Kendari
}

Koresponden Author: liazain03274@gmail.com

\begin{abstract}
Modernization and globalization in the world is characterized by the proliferation of modern religious institutions that attract people. This study attempts to analyze one institution namely Islamic Center Mu'adz bin Jabal (ICM) in Kendari, Southeast Sulawesi. This study indicates that regarded as the Muslim community center with initiation to embrace all groups of society, the program of ICM focuses on education, dakwah, social activities, and other community services. The education curriculum of this institution is using decentralized curriculum called thafidz Al-Quran, the development of infrastructures, and educational programs for kindergarten, elementary school, junior and senior high school. Meanwhile, the pattern of dakwah conducted by ICM is to provide adequate Islamic material, pengajian accessibility targeting every level of community as well as to use social media such as radio, ebsite, and facebook to do dakwah. With the pattern of education and dakwah are offered, ICM receives signifficantly positive response and interest from communities around, also strengthened by the progression of infrastructure development which is relatively faster compared to other educational institutions in Kendari. Moreover, this study confirms that the spirituality of urban society in Kendari obtains the suitable locus because Islamic Centre Mu'adz bin Jabal as the alternative solution to fulfill the religious need of society for any ideology.
\end{abstract}

Keywords: modernity, Pattern of education and dakwah, religiousity, urban society, Islamic Centre Mu'ad bin Jabal

\begin{abstract}
Abstrak
Modernisasi dan globalisasi yang melanda dunia ditandai dengan semakin maraknya bertebaran lembaga atau institusi keagamaan yang cukup modern dan menarik minat masyarakat. Studi ini hendak mengkaji lembaga pendidikan dan dakwah Islamic Centre Mu'adz bin Jabal (ICM) di Kota Kendari Sulawesi Tenggara. Hasil penelitian menunjukan bahwa mengklaim sebagai pusat kegiatan umat Islam dengan maksud untuk merangkul semua kelompok masyarakat,
\end{abstract}


program kerja ICM difokuskan pada pendidikan, dakwah, kegiatan sosial, dan pelayanan umat lainnya. Pendidikan yang ditawarkan oleh ICM adalah menggunakan kurikulum Diknas (Pendidikan Nasional) dengan program khusus tahfidh Al Qur'an, pembangunan infrastruktur dan program pendidikan yang meliputi pendidikan TK, SD, SMP, hingga SMA. Sementara pola dakwah yang dilakukan ICM adalah penyedian materi dan akses pengajian yang komplit dengan menyasar semua kelompok masyarakat serta memanfaatkan media sosial, seperti radio, website, dan facebook. Dengan pola pendidikan dan dakwah yang ditawarkan, ICM secara signifikan menuai respon dan animo positif dari masyarakat sekitar yang juga dikuatkan dengan progresivitas pembangunan infrastruktur yang relatif cepat dibandingkan dengan lembaga pendidikan lainnya di Kota Kendari. Bagaimanapun, studi ini menunjukan bahwa spritualitas masyarakat urban di kota Kendari mendapatkan lokus yang tepat oleh hadirnya Islamic Centre Mu'adz bin Jabal sebagai sebuah alternatif pemenuhan kebutuhan religius masyarakat muslim, terlepas apapun corak idiologi dibaliknya.

Kata Kunci: modernitas, pola pendidikan dan dakwah, religiousitas, kesalehan masyarakat kota, Islamic Centre Mu'ad bin Jabal.

\section{A. PENDAhuluan}

Di Indonesia modernisasi dan globalisasi yang melanda dunia ditandai dengan semakin maraknya bertebaran lembaga atau institusi keagamaan yang cukup modern dan menarik minat masyarakat. Munculnya berbagai institusi keagamaan dan komunitas religius lengkap dengan ajaran yang berbeda dengan ajaran Islam yang selama ini dianut menandakan semakin dinamisnya umat Islam di Indonesia. Pada era tahun 2000-an, Indonesia mengalami religiusitas yang mewabah di hampir semua kategori sosial. Kelompokkelompok majelis zikir banyak bermunculan, mushola- mushola dan tempat sholat khusus disediakan di gedung-gedung perkantoran dan perdagangan. Begitu pula halnya metode dan media dakwah juga menyesuaikan diri, meskipun metode dakwah tradisional tetap masih dipakai. Penyampaian dakwah dewasa ini tidak lagi terbatas pada pola-pola tradisional seperti khutbah, ceramah, pengajian, halakah, tabligh akbar, daurah, dan sebagainya. Penggunaan media modern seperti halnya radio, televisi, sms, internet, rekaman, CD, dan buku-buku khusus dengan disain dan lay out yang menarik menjadi referensi baru bagi pola-pola dakwah di masyarakat ${ }^{1}$. Keuntungan dari pola ini adalah masyarakat menjadi lebih mudah mendapatkan akses

${ }^{1}$ Saefulloh, Aris, "Dakwahtainment: Komodifikasi Industri Media Di Balik Ayat Tuhan", Komunika; Jurnal Dakwah dan Komunikasi, Vol.3 No.2, (Juli-Desember, 2009): 255-26. 
dakwah serta lebih menarik minat mereka, ${ }^{2}$ tetapi dalam beberapa hal menjadikan ajaran dogmatis agama, termasuk Islam bergeser dari hal yang tadinya sakral secara perlahan-lahan menjadi profane. Hal ini dilakukan dengan cara melakukan rekonstruksi dan menyesuaikan perkembangan zaman.

Studi ini hendak mengkaji lembaga pendidikan dan dakwah Islamic Centre Mu'adz bin Jabal (ICM) di Kota Kendari Sulawesi Tenggara yang difokuskan pada pola pendidikan dan pola dakwah yang dibangun hingga dapat menarik minat banyak masyarakat kota Kendari. Tesis bahwa modernitas tidak lantas mematikan fungsi agama dalam kehidupan sosial, tetapi justru malah menguatkannya telah banyak dilakukan lewat penelitian-penelitian sebelumnya. Tulisan Zulkifli yang berjudul "The Ulama in Indonesia, between Religious Authority and Symbolic Power" ${ }^{3}$ mengulas tentang peran dan posisi ulama dalam masyarakat Indonesia kontemporer yang mempengaruhi otoritas keagamaan. Studi tersebut menegaskan bahwa kompetisi otoritas keagamaan di antara kelompok-kelompok keagamaan di Indonesia adalah proses yang tidak pernah selesai. Studi ini juga menegaskan bahwa otoritas keagamaan tidak akan berfungsi dengan baik tanpa kekuatan simbol atau kekuatan agama. Penelitian Zamhari dan Howell, menegaskan bahwa kesalehan masyarakat perkotaan (urban piety) menemukan bentuknya justru dalam masyarakat modern di perkotaan ${ }^{4}$. Temuan tersebut juga dikuatkan oleh studi yang dilakukan Sakai tentang fenomena meningkatnya majelis-majelis pengajian di hotel-hotel berbintang di Jakarta dan keberadaan dompet Dhu'afa SCTV. Studi tersebut membuktikan bahwa modernitas nyatanya justru menguatkan kesalehan bagi banyak orang ${ }^{5}$ Penelitian lain dilakukan oleh Heryanto yang menjelaskan bahwa cara kaum muslim urban dalam merumuskan identitasnya tidak berlangsung secara otonom yang didukung oleh media baru dan menyediakan ruang kontestasi bagi masyarakat dalam upaya pembentukan identitas. Hal ini diwujudkan dalam budaya massa, dan budaya pop, seperti lewat film, televisi, video, facebook, dan

2 Farihah, Irzum, "Media Dakwah Pop", AT-TABSYIR, Jurnal Komunikasi Penyiaran Islam, Vol. 1, No 2, (Juli-Desember, 2013): 25-45.

${ }^{3}$ Zulkifli. "The Ulama in Indonesia; between Religious Authority and Symbolic Power”. Jurnal Miqot, Vol. 37, No. 1, (Januari-Juni 2013): 180-197.

${ }^{4}$ Djamhari, Arif\&Howell, Julia Day, "Taking Sufism to the Streets; Majelis Zikir and Majelis Shalawat as New Venue for Popular Islamic Piety in Indonesia”. Review of Indonesia and Malasyian Affairs, Vol. 46 No.2, (2012): 47-75.

5 Sakai, Minako, "Ethical Self-Improvement in Everyday Life: Propagating the Islamic Way of Life in Globalised Indonesia", Dipresentasikan Dalam 18th Biennial Conference of the Asian Studies Association of Australia di Adelaide, 5-8 July 2010. 
berbagai jenis media sosial lainnya) ${ }^{6}$. Studi-studi tersebut menegaskan bahwa religiusitas dan masyarakat perkotaan bisa berjalan secara seiring dan bahkan dalam modernitas tersebut religiusitas justru bertumbuh dengan cukup subur. Studi ini bagaimanapun hendak menguji sekali lagi tentang temuan-temuan tersebut. Perbedaan studi ini dengan studi-studi sebelumnya adalah pada fokus dan lokus yang langsung mengarah pada intitusi pendidikan agama dan dakwah Islamic Centre (ICM) Mu'adz bin Jabal sebagai muara religiusitas masyarakat urban kota Kendari. Bagaimana institus ini mampu menawarkan dan menyebarluaskan pola pendidikan dan pola dakwah dengan menggunakan media modern, pembangunan infrastruktur yang progresif dan modern, pendekatan yang lebih persuasif dan massif dalam berbagai kegiatan pendidikan dan dakwah, baik secara formal maupun nonformal hingga akhirnya dapat menarik minat masyarakat perkotaan, seperti halnya kota Kendari.

Membicarakan soal keberagamaan atau religiosity adalah wacana yang menimbulkan perdebatan, terutama pada persoalan apa yang menjadi penanda keberagamaan atau religiusitas (religiosity). Keberagamaan (religiosity) adalah persoalan komitmen yang mengacu kepada bagaimana keberagamaan itu dicirikan atau bagaimana menjadi religius yang sebenarnya. Salah satu kunci perdebatan tersebut sebagaimana disebutkan Hassan. adalah keislaman harus dapat terbukti lewat sikap atau perbuatan, lewat etika, dan pengetahuan. ${ }^{7}$

Keberagamaan oleh karenanya tidak hanya terbatas pada salah satu aspek dan tidak pula cukup dilihat dalam periode yang pendek. Mengamati Islam adalah meneliti pada tataran "discursive tradition", pada "practical Islam", pada "discourse". ${ }^{10}$ Konsep "discursive tradition" bagi Asad mengacu pada aspek yang bagaimana keotentikan tersebut diterapkan dan kriteria yang bagaimana dia mendapatkan pembenaran. Islam sebagai tradisi dengan corak keberagamaan masyarakatnya dicirikan oleh rasionalitas atau

${ }^{6}$ Heryanto, Ariel, "Kelas Menengah yang Majemuk", dalam Hadi Jaya, Kelas Menengah Bukan Ratu Adil, (Yogyakarta: Tiara Wacana, 1994).

7 Hassan, Rifaat. "On Being Religious: Patterns of Religious Commitment in Muslim Societies", Faithlines: Muslim Conception of Islam and Society, (USA: Oxford University Press, 2003), 437.

8 Anjum, Ovamir, "Islam as a Discursive Tradition; Talal Asad and His Interlocutors, Comparative Studies of South Asia, Africa, and The Midlle East, Vol. 27, No. 3, (2007): 656-672.

9 Ali, Muhammad, "Muslim Diversity; Islam and Local Tradition in Java and Sulawesi, Indonesia", IJISIM (Indonesian Journal of Islam and Muslim Societies), Vol. 1, No. 1, (2011): 1-35.

${ }^{10}$ Bowen, John Robert, Muslim through Discourse; Religion and Ritual in Gayo Society, (United Kingdom: Princenton University Press, 1993). 
alasan kebenaran yang berasal dari teks agama, sejarahnya, dan institusinya. Disebut dengan paktek-praktek Islam sebab ia diotorisasi oleh tradisi diskursif dalam Islam (entah oleh alim ulama, khatib, sufi, syekh, atau para orang tua) dan ditujukan untuk muslim. ${ }^{11}$ Ia memiliki sejarah tersendiri yang menghubungkan masa lalu (masa dimana praktek keberagamaan tersebut ditetapkan) dan masa yang akan datang (bagaimana praktek keberagamaan tersebut terus berlangsung pada masa mendatang) lewat pelaksananya pada masa kini (bagaimana ia dihubungkan dengan praktek, institusi, dan kondisi sosial yang lain).

Dengan demikian, keberagamaan (religiosity) masyarakat adalah lebih pada soal praktis, bagaimana masyarakat mempraktekkan agama mereka dan apa yang mereka lakukan berpijak pada agama dan keyakinan tersebut. Sebagaimana ditegaskan Miller dan Bronson bahwa titik tekan agama ada pada praktek bukan apa yang dipikirkan, lebih pada persoalan bagaimana ia dimengerti, bukan diyakini, bukan pada persoalan benar salahnya tetapi pada ampuh tidaknya. ${ }^{12}$ Dengan demikian, apapun yang menjadi latar belakang dan keberagamaan masyarakat, ia menjadi wilayah praksis agama.

Religiusitas tidak bisa dilepaskan dari respon masyarakat itu sendiri terhadap modernitas, pada bagaimana masyarakat memaknai agama dalam kehidupan modern. Tesis tentang kebangkitan religiusitas pada abad modern ini dimulai pada awal tahun 1990-an, ketika Naisbitt dan Aburdene dalam bukunya "Megatrend 2000" meramalkan fenomena kebangkitan spiritualitas beragama. ${ }^{13}$ Merujuk pada tesis tersebut secara umum, bisa ditemukan gairah dan semangat yang meningkat dari masyarakat dalam aspek keberagamaan. Gairah dan semangat tersebut muncul dalam bentuk keaktifan dan antusiasme untuk mengikuti aneka ragam kegiatan yang bercorak keagamaan.

Keberadaan institusi pendidikan keagamaan Islamic Centre Mu'adz bin Jabal (ICM) cukup fenomenal sebab progresivitasnya mampu mengalahkan institusi dan lembaga keagamaan sebelumnya yang lebih dahulu masuk ke kota Kendari. Progresivitas yang ditunjukkan institusi keagamaan ini dapat dilihat dari kelengkapan fasilitas infrastruktur, kurikulum pendidikan dan dakwah yang menyentuh hampir semua jenjang usia, pola dakwah yang intensif dan menggunakan media radio, TV, dan blog, juga tawaran fasilitas dan pelayanan keagamaan yang komplit.

11 Asad, Talal, The Idea of an Anthropology of Islam, Occasional Paper Series, (Center for Contemporary Arab Studies. Georgetown University, Washington D.C, 1986).

${ }^{12}$ Dalam Budiwanti, Erni, Islam Sasak; Wetu Telu versus Wektu Lima, (Yogyakarta: LkiS, 2000).

13 Naisbitt, John \& Aburdene, Patricia, Megatrend 2000, (New York: William Morrow \& Company, 1990). 
Progresivitas ICM juga bisa dilihat dari animo masyarakat yang cukup besar terhadap keberadaan Islamic Centre Mu'adz bin Jabal. Lokasi ICM yang berada dekat dengan perguruan tinggi negeri maupun swasta, seperti kampus UHO (Universitas Haluoleo), Poltekes Kemenkes Kendari, Akademi Keperawatan PPNI, dan Akademi Keperawatan Mandala Waluya turut menjadikan jama'ah aktif lembaga keagamaan ini lebih banyak berasal dari kalangan masyarakat dengan tingkat pendidikan relatif tinggi. Dengan animo masyarakat yang semakin tinggi, beberapa cabang sudah mulai dibuka di beberapa kabupaten/kota di Sulawesi Tenggara, seperti di Labibia, Wakatobi, dan satu cabang lagi berada di Boulevard Kota Kendari. Studi ini menfokuskan pada keberadaan Islamic Centre Mu'adz bin Jabal (ICM) di Kota Kendari, terutama pada pola pendidikan dan dakawah yang diberikan sehingga mampu menarik minat masyarakat sekitar untuk menjadi jama'ah aktif.

\section{B. SEKILAS ISLAMIC CENTRE MU'ADZ BIN JABAL}

Islamic Centre Mu'adz bin Jabal memiliki latar belakang yang didasarkan pengalaman pendirinya, yaitu Ustadz Zezen Zainal Mursalin, Lc. Ide pendirian Islamic Centre Mu'adz bin Jabal bermula dari pengalaman yang pernah diikuti Ustadz Zezen (UZ) dalam mengelola ICC (Islamic Cultural Centre) di Damam, Arab Saudi. Selama di sana, UZ terinspirasi oleh keberadaan ICM tempatnya bekerja. Pendirian Islamic Cultural Centre (ICC) sendiri bermula dari usulan Abdullah Al-Ahkam, seorang ahli IT agar melaksanakan da'wah ke kamp-kamp tentara AS di perang Teluk. Ide tersebut ternyata mendapatkan sambutan yang baik. Salah satu kasus yang mengusik para pendiri ICC pada masa perang teluk tersebut adalah suara Adzan bagi para tentara As dianggap sebagai genderang/tabuhan tanda peperangan. Karena itulah, Islamic Cultural Centre (ICC) digagas sebagai upaya memberikan informasi yang benar tentang Islam, termasuk kesalahpahaman tentang suara adzan. Upaya tersebut menunjukkan hasil yang sangat signifikan, terbukti dengan masuknya 3.500 tentara AS menjadi muslim. Keberadaan ICC dalam memberikan informasi yang benar dan lurus tentang Islam dan praktek ibadahnya akhirnya membuat kegiatan ICC menyebar ke seluruh dunia. UZ kemudian pulang dari Damam pada tahun 2004 dan mulai aktif di pondok pesantren milik orang tuanya di Polinggona, Kolaka. Dari sanalah UZ mulai merancang berbagai kegiatan pendidikan dan dakwah hingga pada akhirnya mendirikan Islamic Centre Mu'adz bin Jabal Kendari dan mulai membangun infrastruktur mulai tahun 2007.

Islamic Centre Mu'adz bin Jabal Kendari merupakan unit kegiatan dari Yapiba (Yayasan Pendidikan Islam Baitul Arqam) Polinggona yang berada di Kab. Kolaka. Yapiba berdiri pada tahun 1988 yang diawali dengan 
satu lembaga pendidikan, yaitu Madrasah Tsanawiyah. Pada tanggal 8 Agustus 1999, lembaga pendidikan ditambah dengan didirikannya pesantren dan Madrasah Aliyah (setingkat SMA). Islamic Centre Mu'adz bin Jabal yang berada di Kota Kendari ditetapkan dengan SK Yayasan Pendidikan Islam Baitul Arqom dan diresmikan oleh Walikota Kendari pada tanggal 12 September 2009 (12 Syawal 1420 H). Islamic Centre Mu'adz bin Jabal dilegalisasi dengan dengan Akta Notaris No. 63 pada tanggal 24 September 2013 oleh Notaris M. Asman Amanullah, SH. dan legalitas SK Menteri Hukum \& HAM Nomor AHU-7920.AH.01.04 Tahun 2013. Lokasi Islamic Centre Mu'adz bin Jabal terletak di Jl. Prof. Abdur Rauf Tarimana Kelurahan Kambu Kecamatan Kambu Kota Kendari Sulawesi Tenggara. Pendirian Islamic Centre ini bertujuan mengajak kaum muslimin memurnikan ibadah kepada Allah dan meneladani Rasulullah saw. Disamping itu keberadaanya juga dimaksudkan untuk membantu pemerintah dalam membangun moralitas bangsa yang senantiasa dilandasi Al-Qur'an dan As-Sunnah. Selanjutnya, untuk memudahkan penyebutan, Islamic Centre Mu'adz bin Jabal disingkat menjadi ICM.

Sampai saat ini ICM sudah memiliki beberapa cabang kegiatan pendidikan dan dakwah, di antaranya adalah dibukanya SD pada tahun 2010, SMP pada tahun 2012, SMA dan Program Kaderisasi Imam dan Dai (Prokid) di Boluverd pada tahun 2015. Semua lembaga pendidikan mulai TK hingga SMA dan Program Kaderisasi Imam dan Dai (Prokid) dipusatkan di Kota Kendari. Sementara itu telah dibuka pula Panti Asuhan di Tinaggea, Konawe Selatan pada tahun 2014. ICM di Labibia Kec. Mandonga, Kota Wanci Kabupaten Wakatobi, Kabupaten Raja Ampat Papua dibuka pada tahun 2013. Sekarang sedang dalam proses membuka cabang di Bandung, Jawa Barat dan Bogor.

Alasan didirikannya ICM yang berada cukup jauh dari tempat domisili Yayasan bertujuan untuk mempercepat dan memperluas proses kegiatan da'wah dan sosial kepada masyarakat luas. Pilihan membuka cabang ICM di beberapa kota terkadang bersifat kondisonal dan sesuai dengan misi yang diemban ICM dalam menyebarkan dakwah Islam. Pilihan membuka cabang di Kota Kendari adalah karena Kota Kendari dianggap sebagai tempat strategis bagi penyiaran dakwah Islam. Dibandingkan dengan Kolaka misalnya, Kota Kendari lebih kondusif dari segi keamanan, toleransi umat beragama, kemudahan akses informasi dan komunikasi, kemudahan akses jalan, sarana dan prasarana, serta masyarakat yang lebih modern dari segi pendidikan dan pemahaman agama. Sementara di Kolaka akses komunikasi dan informasi agak terbatas, oleh sebab belum terdapat bandara di tempat tersebut. Di samping itu, jalan-jalan banyak yang masih rusak ketika itu. Sehingga, Kota Kendari dianggap dapat lebih mengembangkan program 
dakwah yang diusung ICM. Dengan kondisi infrastruktur dan kondisi masyarakat Kota Kendari demikian, ICM di tempat ini diharapkan akan cepat berkembang dan daya jangkaunya lebih luas.

Dipilihnya Wakatobi sebagai tempat untuk membuka cabang baru ICM oleh sebab di tempat ini belum terdapat konsep pendirian pesantren. Di samping itu, di daerah ini kebetulan ada donatur yang membeli tanah dan diwakafkan kepada ICM. Sementara itu, pilihan lokasi di Raja Ampat juga dengan alasan yang kurang lebih sama dengan pendirian ICM di Wakatobi, yaitu belum terdapatnya konsep pesantren. Di Raja Ampat, ICM justru menjadi yang pertama kali hadir sebagai Islamic Centre. Menurut penuturan UZ, yang dibidik pertama kali sebetulnya adalah Manokwari, tetapi melihat kondisi kuatnya penginjilan disana menjadi kendala tersendiri, sementara di Raja Ampat mayoritas penduduknya adalah muslim. Alasan lainnya adalah Raja Ampat secara historis merupakan peninggalan kerajaan Islam Tidore. Peninggalan raja Islam artinya akar budaya dan sosial Islam masih bisa digali dan ditemukan di wilayah ini. Alasan lain adalah banyaknya anak-anak Papua yang dibawa ke ICM Kendari untuk disekolahkan di Program Kaderisasi Imam dan Da'i (Prokid). Disamping itu, dengan membuka cabang di Raja Ampat, akan dapat membangun SDM agar bisa membina kehidupan keagamaan di tempat tersebut. Alasan lain adalah bahwa beberapa donatur dari Arab Saudi menghendaki pembangunan di Papua. Di Raja Ampat sendiri, lokasinya adalah tanah wakaf yang berasal dari satu suku yang penduduknya terdiri atas Islam dan Nasrani. Bahkan dalam penyambutan Menteri Agama untuk meresmikan ICM, banyak panitia penyambutan yang merupakan kaum Nasrani. ICM yang ada di Wakatobi dan Raja Ampat sudah diresmikan oleh Menteri Agama RI, Drs. H. Lukman Hakim Saifuddin.

\section{POLA PENDIDIKAN DAN POLA DAKWAH ICM}

ICM sebagaimana tujuan awal pendiriannya adalah memberikan pelayanan pendidikan, dakwah dan sosial kepada masyarakat luas dalam bentuk penyelenggaraan pendidikan formal dan nonformal. Bentuk kegiatan lembaga ini tercantum dalam keputusan pengurus Yapiba (Yayasan Pendidikan Islam Baitul-Arqam) Kolaka, nomor 002/KEP/YAPIBA/I/2015, tanggal 4 Januari 2015, tentang organisasi dan tata kerja Yapiba bagian tujuh pasal 10. Berdasarkan SK tersebut, maka arah lembaga ini adalah menyelenggarakan pendidikan formal, dakwah, sosial, serta bentuk pelayanan umat lainnya.

Visi yang diemban pendidikan Islamic Centre Mu'adz bin Jabal Kendari adalah menjadikan lembaga berbasis Islam yang unggul dalam bidang sosial/pendidikan, kemanusiaan dan keagamaan, membangun sumber daya manusia (SDM) yang mengantarkan masyarakat berpendidikan, 
berbudaya, berkepribadian dan akhlakul karimah. Sedangkan misi Islamic Centre Mu'adz Bin Jabal Kendari adalah berperan aktif menghimpun dan menyalurkan zakat, infaq, dan shadaqah, menghimpun, mengembangkan, dan mengelola tanah wakaf baik yang berupa barang bergerak (uang) maupun tidak bergerak (tanah), dan menyelenggarakan berbagai layanan sosial dalam membantu pemberdayaan umat Islam ${ }^{14}$.

Beberapa program kerja yang diberikan Yayasan ICM adalah bidang dakwah (keagamaan), bidang sosial, bidang sumber daya manusia dan pendidikan, dan bidang kehumasan. Adapun bidang dakwah (keagamaan) meliputi beberapa hal sebagai berikut 1) menyelenggarakan Program I'dadud Du'at (pembekalan bagi juru da'wah) selama 2 tahun, 2) mengadakan Dauroh Syar'iyyah (pelatihan da'wah berkala) bagi para aktifis da'wah, 3) mengirim para juru da'wah ke daerah yang membutuhkan, 4) mengadakan kajian keIslaman rutin, 5) menyediakan layanan perpustakaan Islam, 6) menyelenggarakan kursus bahasa Arab, 7) menyiarkan radio dakwah Islam, 8) berdakwah dengan memanfaatkan media online, 9) melakukan kerjasama dengan yayasan dan lembaga dakwah lain, 10) menyelenggarakan bimbingan ibadah haji dan umrah ${ }^{15}$.

Beberapa kegiatan ICM di bidang sosial adalah memberikan bantuan kepada korban bencana alam, menyalurkan pakaian layak pakai kepada masyarakat yang membutuhkan, mengadakan kegiatan khitanan massal, qurban, menerima dan menyalurkan zakat, infaq, dan shodaqoh, memberikan pelayanan Posyandu kepada masyarakat di sekitar kompleks Islamic Center Mu'adz Bin Jabal, dan pendistribusian Mushaf Al-Qur'an ${ }^{16}$.

Sementara itu, kegiatan ICM di bidang sumber daya manusia dan pendidikan terdiri atas lembaga pendidikan formal dan informal. Lembaga pendidikan formal adalah Pendidikan Sekolah Taman Kanak-Kanak (TKTQ), Pendidikan Sekolah Dasar Tahfidzul Qur'an (SD-TQ), Pendidikan Sekolah Menengah Pertama Tahfidzul Qur'an (SMP-TQ), Pendidikan Sekolah Menengah Atas Tahfidzul Qur'an (SMA-TQ). Kegiatan Lembaga Pendidikan Non Formal meliputi Program Kaderisasi Imam dan Da'i (Prokid) dan Taman Pengajian Al-Qur'an ${ }^{17}$.

Adapun kegiatan ICM di bidang kehumasan adalah menjalin kerjasama dengan seluruh lapisan masyarakat, menjalin kerjasama dengan lembaga sosial milik pemerintah, menjalin kerjasama program dengan

\footnotetext{
${ }^{14}$ http://icm.or.id/home/about/. Diakses pada tanggal 6 September 2016

${ }^{15}$ Ibid

${ }^{16}$ Ibid

${ }^{17}$ Ibid
} 
instansi pemerintahan, dan mengadakan studi banding kepada lembaga sosial yang telah berhasil ${ }^{18}$.

Pola rekrutmen pengurus, ustadz dan ustadzah di lembaga ICM melalui rekrutmen terbatas, tergantung kebutuhan ICM. Proses yang biasa dilakukan adalah lewat perkenalan dan komunikasi yang intens yang dilakukan sebelumnya dengan UZ atau dengan pengurus yang lain. Hal ini dilakukan untuk menjaga proses penanaman nilai-nilai dakwah Islam lembaga ini agar tetap terjaga sesuai dengan visi dan misi yang diemban ICM.

Biaya operasionalisasi ICM dianggarkan dari dana pendidikan dan donatur yang bersifat tidak tetap. Insentif untuk guru-guru berasal dari biaya pendidikan. Sementara itu, pengurus yang aktif di yayasan atau radio mendapatkan insentif pula dari yayasan atau pengelolaan radio. Satpam di ICM juga dikelola oleh sekolah dan mendapatkan dana insentif dari biaya pendidikan di ICM.

\section{Lembaga Pendidikan ICM}

Pembangunan dan perkembangan ICM relatif lebih cepat dibandingkan dengan lembaga-lembaga pendidikan lain yang sudah lebih dahulu ada, terutama jika disandingkan dengan lembaga Islam lain dengan waktu masuk yang relatif sama di Kota kendari . Hal ini bisa dilihat dari pembangunan infrastruktur yang terus diperbanyak dan diperluas. Pembangunan infrastruktur ini berupa gedung-gedung pendidikan dan pembukaan kelas-kelas baru, pembangunan Wakaf Center di Jl. Boulevard, serta pembangunan gedung baru di Program Kaderisasi Imam dan Da'i (Prokid).

Keberhasilan pembangunan fisik berupa gedung tidak terlepas dari donatur tetap yang berasal dari Arab Saudi (muhsinun), beberapa donatur lain, dan jama'ah ICM. Bantuan dari donatur Arab Saudi diperuntukkan bagi pembangunan gedung dan pembukaan kelas-kelas baru. Sementara donatur lain seperti halnya jama'ah diperuntukan bagi operasionalisasi ICM dalam program-program pendidikan, dakwah, dan sosial.

Pembangunan fisik seperti gedung yang terus mengalami peningkatan menjadi kendala tersendiri bagi para pengurus, sebab tidak berbanding signifikan dengan biaya operasional pendidikan dan dakwah yang diselenggarakan lembaga ini. Tantangan lain adalah ketersediaan Sumber Daya Manusia (SDM) yang belum mencukup, baik tenaga pendidik, maupun SDM untuk menyiarkan dakwah. Untuk mengatasi hal tersebut, biaya operasionalisasi sekolah diperoleh dari biaya pendidikan yang dibayarkan oleh orang tua siswa pada setiap ajaran baru.

18 ibid 
Di samping itu, biaya pelayanan umat dalam bentuk pengajian dan layanan ibadah lainnya dilakukan dengan cara mengajak para jama'ah untuk bersedekah. Tidak sedikit para jama'ah yang menjadi donatur dalam kegiatankegiatan yang diselenggarakan ICM, seperti yang terjadi pada bulan Ramadhan lalu, dimana persediaan makanan dan minuman untuk berbuka puasa serta i'tikaf pada sepuluh hari di akhir bulan Ramadhan berasal dari inisiatif para jama'ah. Secara fisik, tersedianya sarana belajar dan da'wah yang representatif atau modern menjadi satu kemajuan ICM. Secara nonfisik, program-program pengajian dan pelayanan umat baik secara langsung maupun lewat media seperti radio dan facebook menjadi poin penting lainnya dalam menarik minat masyarakat sebagaimana yang dikemukakan Rahman ${ }^{19}$; Haqqani ${ }^{20}$. Jelaslah bahwa ICM yang hidup ditengah masyarakat kota memerlukan media-media modern seperti halnya radio atau facebook untuk menyampaikan pesan-pesan dakwahnya. ICM tidak ingin mengikuti polapola lama yang dengan kehadiran media-media modern akan mempengaruhi otoritas keagamaan tradisional. ${ }^{21}$

Kurikulum pendidikan yang digunakan untuk tingkat SD dan SMA adalah kurikulum pendidikan dan kebudayaan (Dikbud). Berbeda dengan lembaga pendidikan agama, ICM melabelkan pendidikan pada penamaan sekolah umum seperti Taman Kanak-Kanak bukan Raudhatul Athfal, Sekolah Dasar bukan Madrasah Ibtidaiyah, SMP bukan Madrasah Tsanawiyah, SMA bukan Madrasah Aliyah. Meskipun demikian, ICM memiliki program khusus berupa program tahfidz yang mulai diberlakukan sejak TK hingga SMA. Sehingga, meskipun pendidikan formalnya adalah TK, SD, SMP dan SMA, akan tetapi terdapat tambahan program khusus berupa hafalan Qur'an pada semua jenjang sekolah tersebut.

Menurut pengakuan Ustadz Zezen (UZ), pilihan kurikulum Dikbud disesuaikan dengan kondisi setempat atau kebutuhan masyarakat saat itu. Di beberapa tempat seperti di Polinggona, kurikulum yang digunakan adalah kurikulum Kementerian Agama. Awalnya di ICM Kota Kendari pernah pula diterapkan kurikulum Kementerian Agama, akan tetapi minat masyarakat untuk menyekolahkan anaknya tidak sebanyak sekarang. Oleh sebab itu,

${ }^{19}$ Rahman, Fazlur, "Internet and Kyais in Indonesia Negotiation of Authority in a Mediatized Environment”, Heidelberg Journal for Religions on the Internet, Vol. 9 (2015), http://online.uni-hd.de.

${ }^{20}$ Haqqani, Shehnaz, Muslim Televangelists and the Construction of Religious Authority in the Modern World: The Case of Zakir Naik, Tesis di Faculty of Emory College of Arts and Sciences of Emory University, Department of Middle Eastern and South Asian Studies, 2011.

${ }^{21}$ Campbell, Heidi A \& Paul Emerson Teusner, Religious Authority in the Age of the Internet, (Center for Christian Ethics: Baylor University, 2011), 62. 
dalam perkembangan selanjutnya dipilihlah kurikulum pendidikan Dikbud. Lembaga pendidikan ICM terdiri atas beberapa tingkatan pendidikan, mulai dari TQ Islami sampai dengan SMA TQ ditambah dengan Program Pendidikan Imam dan Da'i (Prokid). Sejak dibuka pada tahun 2009, ICM menerima pendaftaran siswa baru yang terus bertambah dari tahun ke tahun.

Untuk tingkat TK, jumlah penerimaan siswa perlahan-lahan bertambah sesuai dengan ketersediaan kelas dan minat masyarakat untuk menyekolahkan anaknya di ICM. Sejak diresmikan oleh Walikota Kendari pada tahun 2009 jumlah siswa TK hanya menerima 10 orang, maka tahun 2016 siswanya bertambah menjadi 83 siswa. Sementara itu jumlah guru sebanyak 15 orang yang semuanya adalah perempuan. Begitu pula halnya dengan SD. Sebelumnya lembaga ini adalah Madrasah Ibtidayah (MI). Perubahan kurikulum dari MI ke SD menurut UZ dilandasi oleh pemikiran bahwa kurikulum keagamaan model takhasus yang menjadi kekhususan ICM dapat lebih diprioritaskan dan juga alasan bahwa bimbingan dan pengawasannya akan lebih intensif. Pada tingkat SD, ICM baru membuka pendaftaran siswanya pada tahun 2011 yaitu sejumlah 45 orang dan pada tahun 2016 bertambah menjadi 370 siswa. Sementara itu, jumlah gurunya hingga saat ini sebanyak 39 orang yang terdiri atas laki-laki 9 orang dan perempuan 30 orang.

ICM menerima pendaftaran siswa SMP baru sejak tahun 2012, berkisar hanya 17 orang siswa dan pada tahun 2016 menjadi 177 siswa dan jumlah guru sebanyak 34 yang terdiri atas 12 guru laki-laki dan 22 guru perempuan. ICM baru menerima siswa untuk tingkat SMA pada tahun 2015 dengan jumlah siswa sebanyak 21 orang dan jumlah guru sebanyak 11 orang dengan jumlah guru laki-laki sebanyak 8 orang dan guru perempuan sebanyak 3 orang.

Sementara itu, program khusus ICM yaitu Program Kederisasi Imam dan Da'i (Prokid) yang mulai dibuka pada tahun 2015 memiliki siswa sebanyak 51 orang dengan jumlah siswa perempuan sebanyak 27 sedikit lebih banyak dari jumlah siswa laki-laki sebanyak 24 orang. Program ini adalah program pendidikan yang berlangsung selama dua tahun. Guru yang mengajar untuk program ini sebanyak 7 orang yang terdiri atas 5 orang guru laki-laki dan 2 orang guru perempuan.

Sebelum mendirikan lembaga pendidikan seperti TK hingga SMA, program awal ICM adalah dakwah yang awalnya difokuskan pada kalangan mahasiswa, bukan pada pendidikan formal. Ia berbentuk kaderisasi imam dan da'i dan sekarang ini menjadi program Prokid (Program Kaderisasi Imam dan Dai). Setelah berjalan satu tahun, program tersebut menemui kendala dalam aspek biaya operasional. Hal ini disebabkan program Prokid bergerak di bidang sosial, sehingga pengurus relatif sulit mendapatkan dana operasional 
untuk program ini. Disamping itu, urgensi program ini belum sepenuhnya disadari oleh masyarakat, sebab belum banyak masyarakat yang tergerak hatinya kala itu untuk memasukan anaknya dalam program tersebut. Kendala ini membuat Yayasan ICM merasa kesulitan menanggung biaya operasional program. Dari situlah mulai timbul ide untuk membuka sekolah dan terus meningkat kelas dan jenjangnya sejak awal dibuka pada tahun 2009.

Saat ini siswa Prokid berjumlah 51 orang dengan jenjang pendidikan SMA dan S1. Rata-rata siswa Prokid disubsidi oleh Yayasan ICM, tetapi ada pula yang hanya membayar biaya makan saja sementara biaya lain-lain ditanggung sepenuhnya oleh ICM. Rata-rata yang menjadi siswa Prokid berasal dari kalangan tidak mampu. Ada pula beberapa yang sesungguhnya orang tuanya mampu untuk membayar, akan tetapi program Prokid dipandang oleh orang tua siswa tersebut tidak menjanjikan masa depan yang cemerlang, maka mereka berlepas tangan dengan keinginan anaknya untuk bersekolah di Prokid. Akhirnya ICM lah yang menanggung biaya pendidikan anak tersebut selama belajar. Masuknya anak tersebut di Prokid lebih banyak didukung oleh motivasi anak dan dukungan dari Prokid sendiri. Cara untuk memotivasi anak-anak yang belajar di Prokid adalah menanamkan keyakinan kepada mereka bahwa aktif di masjid adalah karir yang selalu tersedia dan lebih banyak peluangnya dibandingkan dengan pekerjaan lain. Saat ini, Prokid banyak ditawari dari luar daerah dalam bentuk MOU untuk menjadi imam masjid.

\section{Lembaga Dakwah dan Sosial ICM}

ICM selain mendirikan lembaga pendidikan formal dan non formal, juga memiliki pola pengembangan dakwah yang dilakukan secara tetap dan kontinyu (berkesinambungan). Pola dakwah ICM dilakukan dalam bentuk pengajian yang dilakukan secara rutin dan berkesinambungan serta diperuntukan bagi masyarakat umum. Pengajian tersebut ada yang berbentuk umum dan ada pula yang ditujukan bagi kategori tertentu dan dengan mendasarkan pada tema-tema tertentu. Adapun bentuk-bentuk pengajian ICM bagi masyarakat umum adalah melalui pengajian pekanan/mingguan dengan jadwal a) di masjid ICM, hari Senin, Selasa, Rabu dan Jum'at, jam 18.30 20.00; b) di masjid ICM Bollevard, hari Ahad, jam 18.30 - 20.00; c) di masji BTN Nafa Graha, hari Senin, jam 18.30 - 20.00; d) di masjid ICM Labibia, hari Sabtu, jam $18.30-20.00$.

Sementara itu, ada pula pengajian bulanan yang diperuntukkan bagi pengurus Yayasan dan juga forum kepala sekolah dengan waktu yang dikondisikan atau sesuai dengan kebutuhan/jika diperlukan. Program dakwah yang digagas ICM adalah kajian harian berupa kajian Tafsir Al Muyassar yang diselenggarakan setiap hari mulai pukul 05.15-06.00 di masjid ICM. 
Selain itu, ada pula kajian pekanan, kajian bulanan dan tabligh akbar yang biasanya menghadirkan narasumber dari luar ICM, seperti halnya dari Jawa, Sumatra, dan Arab Saudi. Setiap hari, ICM menjadwalkan kegiatan agama atau pengajian dengan narasumber utamanya adalah Ustadz Zezen Zainal Mursalin.

Kegiatan-kegiatan tersebut dipusatkan di masjid ICM dengan jadwal 1) Ahad, yaitu jurnal interaktif dengan Ustadz Zezen sebagai narasumber yang dilaksanakan pada pukul 05.15-06.15; 2) Selasa, kajian Kitab Bulughul Marom pada pukul 18.30-19.30 dengan narasumber Ustadz Zezen; 3) Rabu, kajian tentang pengaruh perbedaan kaidah-kaidah ushul terhadap perbedaan pendapat para ulama pada pukul 18-30-19.30 dengan pemateri Ustadz Ahmad Laode, Lc; 4) Kamis, kajian tentang 40 Hadist Wanita pada pukul 17.00-18.00 dengan pemateri Ustadz Zezen. Ada pula program Tahsin Al Qur'an pada pukul 18.00-19.00 dengan Ustadz Dhamaruddin, Lc. 5. Jum'at dengan kajian Mukhtashor Zaadul Maad pada pukul 18.30-19.30 dengan pemateri Ustadz Zezen. Selain program harian dan pekanan sebagaimana disebutkan di atas, ICM juga menyelenggarakan kegiatan sebulan sekali pada Hari Ahad berupa pengajian keluarga muslim pada pukul 16.30-18.00 oleh Ustadz Zezen.

Selain itu, ada pula pengajian yang diperuntukkan bagi kelompokkelompok tertentu, misalnya bimbingan baca tulis Al Qur'an bagi bapakbapak dan ibu-ibu. Untuk bapak-bapak dijadwalkan setiap senin sore/ba'da maghrib dan untuk ibu-ibu setiap ahad jam 08.00-10.00. Khusus untuk ibuibu selain bimbingan baca tulis Al Qur'an ada pula pengajian dalam bentuk tematik. Seperti yang diprogramkan oleh Bidang Pendidikan Divisi Muslimah ICM dalam kegiatan Halaqah Tahsin Tilawah, Halaqah Tajwid tahfidz pada tingkat pemula maupun lanjut dan kajian pekanan. Adapun jadwal yang ditetapkan adalah sebagai berikut:

A. Halaqoh Tahsin

1. Kelas A bertempat di masjid Mu'adz bin Jabal Lt. 2 dengan pembimbing Ummu Umar, Ummu Afifah, Ummu Uwais, dan Ummu Hanif. Kelas ini berlangsung pada Hari Ahad, jam 08.0009.30.

2. Kelas B bertempat di rumah Ummu Umar dengan pembimbing Ummu Umar pada Hari Senin pukul 16.15-17.30.

3. Kelas C bertempat di masjid Mu'adz bin Jabal Lt.2 dengan pembimbing Ummu Wafa, Ummu Syifa, Ummu Uwais pada Hari Jum'at, pukul 09.00-10.30.

B. Halaqoh Tahfidz

1. Kelas A diperuntukkan bagi ummahat/ibu-ibu dan akhwat yang jumlah hafalannya sudah banyak. Kelas ini berupa setoran 
hafalan minilal 1 lembar dengan pembimbing Ummu Umar dan berlangsung di rumah beliau pada Hari Selasa pukul 16.1517.30 .

2. Kelas $\mathrm{B}$ yaitu setor hafalan 1 halaman dimulai dari surat $\mathrm{Al}$ Baqorah dengan pembimbing Ummu Umar, Ummu Afifah, Ummu Mifta, Ummu Aiyanah, Ummu Herlina. Kelas ini berlangsung di rumah Ummu Umar pada Hari Rabu pukul 16.1517.30.

C. Pengajian Pekanan

1. Kajian buku Tanya Jawab tentang Rukun Islam dengan pemateri Ummu Wafa bertempat di Masjid Mu'adz bin Jabal Lt.2 pada Hari Ahad pukul 09.30-11.00.

2. Kajian 40 Hadist pilihan tentang wanita (Al Arba'uun An Nisaaiyah) dengan pemateri Ustadz Zezen Zainal Musralin, Lc di Masjid Mu'adz bin Jabal Lt.2 pada Hari Kamis pukul 16.3017.30

3. Kajian buku Ensiklopedi Sholat dengan pemateri Ummu Wafa bertempat di ruang TK ICM pada Hari Jum'at pukul 10.30-11.30

D. Halaqoh Tadarrus Al Qur'an

Kegiatan ini berupa program rutin yang berlangsung di Masjid Mu'adz bin Jabal Lt.2 pada setiap Hari Selasa pukul 16.00-17.30. Pada kegiatan Ramadhan tahun ini, Halaqoh Tadarrus Al Qur'an diadakan juga pada Hari Ahad pukul 08.00-10.00 dan dilanjutkan dengan kajian Fiqhun Nisa oleh Ustadzah di ICM.

Selain kegiatan pengajian tersebut di atas, ICM juga menyediakan pengajian TPA untuk anak-anak sekitar yang ingin belajar dan juga program les privat BTQ yang bisa dilayani di lembaga ini.

Pengajian yang dilaksanakan oleh ICM tidak bisa dilepaskan dari keberadaan radio yang dinamakan Radio Mu'adz bin Jabal pada rekwensi 94,3 FM yang mulai beroperasi pada tahun 2009. Radio ini menjadi media dakwah yang sangat efektif dalam menyampaikan pesan-pesan Islam kepada masyarakat luas. Keberadaan radio Mu'adz bin Jabal bukan saja menjadi media dakwah bagi masyarakat yang ingin mengetahui tentang Islam secara lebih komprehensif, tetapi juga menjadi media informasi dan komunikasi. Media informasi, karena radio ini menjadi ladang informasi agama berikut persoalan-persoalan yang melingkupinya bagi masyarakat umum. Ia juga menjadi media komunimasi oleh sebab lewat radio ini masyarakat luas dan siapapun bisa berkomunikasi dengan ustadz terkait masalah-masalah agama 
ataupun kebingungan mereka memahami agama, bahkan masalah pribadi dan masalah paham dan praktek ibadah sehari-hari.

Jadwal rutin siaran radio ini dimulai pukul 04.00 subuh sampai jam 23.30. Programnya ada yang bersifat langsung-interaktif dan ada pula yang bersifat rekaman. Personil radio terdiri atas sepuluh orang. Dari sepuluh orang tersebut ada yang berada di manajemen, ada pula yang menjadi teknisi. Kru radio terdiri atas enam orang dan narasumber yang terdiri atas narasumber lokal dan narasumber luar Sulawesi, misalnya dari Jawa Timur (Surabaya) atau Solo atau juga yang berasal dari Arab Saudi. Narasumber luar biasanya adalah para ustadz yang sedang studi di Arab Saudi atau kenalan Ustadz Zezen di daerah Jawa ataupun yang memiliki satu visi dengan ICM. Mereka ini adalah pegiat dakwah di daerah tersebut. Pengajian dengan narasumber dari Arab Saudi biasa pula dilangsungkan melalui skype yang dipasang di layar lebar di masjid ICM. Jadi ceramah dari Arab Saudi bisa didengar oleh para jama'ah melalui media elektronik. Oleh karena ia berbahasa Arab, maka ada penerjemah dari ICM yang akan memberi pemahaman kepada para jama'ah tentang materi yang diberikan narasumber. Kriteria mereka menjadi narasumber di ICM menurut penjelasan UZ adalah pemahamanya yang sama tentang ahli sunah waljama'ah. Narasumber yang didatangkan di ICM juga terkadang berasal dari rekomendasi dari rekanrekan sesama Asosiasi RadioTivi Sunnah se-Indonesia (Advisi), oleh sebab radio Mu'adz telah tergabung dalam Asosiasi ini.

ICM pernah memiliki ide untuk melebarkan media dakwah melalui televisi dengan cara membentuk televisi dakwah sendiri. Akan tetapi setelah mengadakan studi banding ke studio-studio tv satelit di Indonesia, ternyata penggunaan satelit televisi membutuhkan dana yang cukup besar (sebanyak kurang lebih ratusan juta rupiah). Kendala dana tersebutlah yang membuat ide untuk membuat televisi sendiri menjadi tertunda. Pengadaan televisi lebih besar dananya oleh sebab harus mengkontak satelit yang membutuhkan dana besar. Berbeda dengan radio yang hanya mengandalkan frekwensi/modulasi FM, jadi ia sifatnya lokal. Sehingga biaya operasinalisasi karyawan tidak terlalu membutuhkan dana besar.

Selain radio, penggunaan media sosial juga tidak luput dari aktivitas dakwah lembaga ini. Mereka memiliki facebok dengan nama Mu'adz bin Jabal. Selain itu, kegiatan-kegiatan ICM juga bisa diunduh di website ICM dengan laman http://www.icm.or.id. Dalam website ini diinformasikan tentang kegiatan pelayanan keagamaan yang dilakukan oleh ICM kepada masyarakat, baik yang dilakukan secara mandiri maupun kerja sama dengan stakeholder lainnya, seperti Pemda Kota Kendari, Pemprov, ataupun dengan Polda Sultra. 
Penyebaran dakwah juga dilakukan dengan cara mendirikan masjidmasjid di kota Kendari dan membinanya sekaligus. Masjid yang menjadi asuhan ICM adalah Islamic Center Mu'adz bin Jabal Cabang Konawe Selatan, Sulawesi Tenggara; Islamic Center Mu'adz Bin Jabal Cabang Wakatobi, Sulawesi Tenggara; Islamic Center Mu'adz Bin Jabal Cabang Raja Ampat, Papua Barat, dan sedang dalam proses pendirian Islamic Center Cabang Bandung, Jawa Barat.

Sentra aktivitas keagamaan yang dipusatkan di masjid dan juga pembangunan banyak masjid binaan ICM di kota Kendari adalah wujud dari keinginan untuk mengembalikan fungsi masjid sebagai pusat aktivitas keagamaan kaum muslim sebagaimana yang dulu diinisiasi oleh Rasulullah SAW pada pembangunan masjid pertama di Madinah. Masjid dalam hal ini adalah representasi nilai religius. Ekomadyo menjelaskan hal ini sebagai bagian dari prinsip urbanitas dalam Islam, dimana religiusitas mengendalikan hal duniawi dengan tanpa harus membentangkan jarak denganya. ${ }^{22}$

Model pembinaan masjid dilakukan dengan memberdayakan anakanak SMA pada kelas 2 dan anak-anak Prokid (Program Kaderisasi Imam dan Dai) untuk mengisi pengajian, pembinaan BTQ dan juga memimpin sholat jama'ah di masjid-masjid tersebut. Saat ini jumlah masjid binaan ICM sebanyak 20 masjid. Dana pembangunan masjid-masjid tersebut berasal dari donasi secara individu oleh donatur yang berasal dari Arab Saudi. Umumnya para donatur ini ingin bersedekah atau memberikan wakaf yang pahalanya ditujukan bagi keluarganya, misalnya orang tuanya yang sudah meninggal. Inisiatif para donatur Arab Saudi tersebut menurut UZ disebabkan karena dibatasinya izin untuk membangun masjid di Arab Saudi oleh sebab masjid sudah terlalu banyak dan tak ada lagi tanah untuk membangun masjid di sana. Pembangunan masjid yang dibantu oleh donasi dari orang-orang Arab saudi (muhsinun) meliputi pembangunan fisik, operasionalisasi masjid dan SDM. ICM dalam hal ini berfungsi sebagai penyalur atau pelaksana donasi.

Untuk masjid ICM sendiri dibangun pada tahun 2007 dengan luas 9x9 meter dengan kapasitas jama'ah sebanyak 150 orang. Hingga tahun 2016, masjid ini telah mengalami dua kali pemugaran dan perluasan. Pada tahun 2012 masjid dibangun dua lantai dengan luas 13x13 meter dengan daya tampung jama'ah sebanyak 600 orang. Pada tahun 2015, masjid kembali direhab dengan perluasan sebanyak $13 \times 16$ meter dengan kapasitas jama'ah sebanyak 800 orang.

${ }^{22}$ Ekomadyo, Agus S, "Kajian Relasi Sosio-Spasial Antara Masjid Dan Pasar: Kajian Atas Kontribusi Islam Dalam Urbanitas Kontemporer", Seminar Nasional Arsitektur Islam 2, Universitas Muhammadiyah Surakarta, 2012. 
Selain itu, ICM juga menyediakan bentuk pelayanan sosial kepada umat, salah satunya dalam bentuk penyelenggaraan jenazah hingga pemakaman. Dalam kegiatan sosial ini, ICM menyediakan sarana dan peralatan yang dipelukan (kain kafan dan mobuil jenazah), penanganan hingga pada penguburan, bahkan juga lokasi yang sedianya ditempatkan di Nanga-Nanga. Namun demikian, menurut UA, meskipun jama'ah meminta bantuan ICM untuk menangani penyelenggaraan jenazah bagi keluarganya, akan tetapi keluarga lebih cenderung menentukan lokasi pemakamannya sendiri.

Layanan sosial lain yang dilakukan ICM adalah memberikan bantuan kepada para korban bencana alam, bantuan pakaian layak pakai kepada masyarakat yang membutuhkan, khitanan massal, penyelenggaraan dan pemotongan qurban, menerima dan menyalurkan zakat, infaq, dan shodaqoh, memberikan pelayanan Posyandu kepada masyarakat di sekitar kompleks Islamic Center Mu'adz bin Jabal, dan juga banyak mendistribusikan Mushaf Al-Qur'an kepada masyarakat.

\section{ICM DAN BANGKITNYA RELIGIUSITAS MASYARAKAT URBAN}

Progresivitas ICM dapat dilihat secara kasat mata dari pembangunan infrastruktur yang cukup cepat dibandingkan dengan institusi pendidikan agama lainnya di kota Kendari. Hal ini disebabkan oleh jumlah donator yang banyak membantu pembangunan ICM, baik yang berasal dari Arab Saudi maupun donator mandiri yang berasal dari jama'ah loyal ICM yang kebanyakn terdiri atas kalangan ekonomi menengah ke atas. Kesediaan masyarakat untuk menjadi jama'ah loyalis atau bahkan menjadi donator tetap digerakan secara sadar dan otomatis yang salah satunya oleh dorongan pemenuhan nilai-nilai keagamaan atau religiusitas dalam diri mereka. Keberagamaan kerananya adalah persoalan bagaimana makna agama di implementasikan pada hal-hal keseharian, pada soal praktis. Sehingga, apa yang dipraktekan oleh masyarakat berdasarkan pada keyakinan agama yang mereka anggap sebagai kebenaran ${ }^{23}$. Maka menjadi benarlah jika dikatakan bahwa keberagamaan sesungguhnya adalah apa yang ada pada praktek bukan apa yang dipikirkan, bagaimana ia dimengerti bukan diyakini, tidak melihat benar salahnya tetapi pada ampuh tidaknya.

Para jama'ah yang menjadi donator di ICM adalah jama'ah yang aktif baik secara pribadi sering mengikuti pengajian para ustadz di ICM maupun yang menyekolahkan anaknya pada jenjang pendidikan di ICM. Kesediaan para jama'ah loyalis tersebut untuk menjadi donatur tidak terepas dari daya

${ }^{23}$ Miller\&Bronson dalam Budiwanti, Erni, ..., Loc Cit. 
tarik ICM dalam menawarkan pengetahuan dan pemahaman agama masyarakat kota Kendari. Kehadiran ICM telah mendapatkan tempat di hari masyarakat kota dalam hal menawarkan pengetahuan agama yang boleh jadi belum pernah didapatkan selama ini atau belum mampu diberikan leh institusi pendidikan dan instritusi dakwah lainnya di kota Kendari. Menjadi rasional apa yang dikemukakan Asad dengan konsep "discursive tradition" ${ }^{24}$ bahwa ICM dengan segala daya tarik yang dimilikinya, baik secara fisik maupun pola pendidikan dan dakwahnya mendapatkan pembenaran oleh masyarakat kota yang secara otomatis mencetuskan religiusitas masyarakat perkotaan (urban piety). ICM mendapatkan pembenaran (alasan kebenaran) dan dianggap rasional oleh sebab teks agama yang coba diwacanakan dan diotorisasi para ustadz ICM (khususnya Ustadz Zezen) dengan mendasarkan pada sumber ahlu sunnah waljamah. Konsep ini akhirnya menjadi corak Islam yang berterima oleh masyarakat luas dan tidak harus dipandang sebagai Islam yang bercorak wahabiah apalagi radikal. Tidak dapat dipungkiri pula bahwa dalam banyak perbincangan di masyarakat, pola pendidikan dan dakwah yang diusung ICM juga dianggap sebagai corak salafi, bahkan juga dianggap mengusung ajaran wahabi oleh sebab donator dan tamu-tamu narasumber pengajian banyak yang berasal dari undangan kedutaan besar Arab Saudi. Corak salafi atau wahabisme yang dilekatkan sebagian masyarakat kepada pola dakwah yang dilakukan ICM menandakan bangkitnya gerakan fundamentalisme agama lewat representasi lembaga keagamaan ini. Ia justru lahir dalam rahim globalisasi, sehingga ia dibaca sebagai anak kandung modernitas ${ }^{25}$. Hal ini juga bisa dibaca dari tawan-tawaran yang diberikan ICM dimana mereka menyuarakan pentingnya kembali kepada agama untuk mengimbangi arus modernitas yang dianggap telah terlampau jauh dari jalan Allah. Kaum fundamentalis menawarkan alternatif cara hidup sebagai counter terhadap kehidupan modern yang dianggap sudah melenceng dari garis Tuhan. ${ }^{26}$

Meningkatnya religiusitas yang melanda masyarakat kota Kendari adalah sesuatu yang lumrah dalam masyarakat perkotaan, sebagaimana ramalan Naisbitt dan Aburdene yang mengatakan bahwa pada zaman modern muncul gairah dan semangat spritualisme dan kebangkitan beragama pada masyarakat, terutama yang tinggal di wilayah-wilayah perkotaan ${ }^{27}$.

\footnotetext{
${ }^{24}$ Asad, Talal, The Idea of an Anthropology of Islam, Occasional Paper Series, (Center for Contemporary Arab Studies. Georgetown University, Washington D.C, 1986).

${ }^{25}$ Hamdi, Ahmad Zainul, “Agama di Tengah Jaring-jaring Dunia Modern”, Jurnal Religió: Jurnal Studi Agama-Agama, Vol. 3, No. 2, (September, 2013): 187-208.

${ }^{26}$ Hasan, Noorhaidi, Laskar Jihad: Islam, militansi, dan Pencarian Identitas di Indonesia PascaOrde Baru, (Jakarta: LP3ES \& KITLV-Jakarta, 2008), 31

${ }^{27}$ Naisbitt, John \& Aburdene, Patricia,..., Loc Cit.
} 
Fenomena demikian dapat ditemukan dalam antusisme masyarakat kota Kendari khususnya para jama'ah loyalis yang mengikuti secara aktif berbagai kegiatan pengajian, dakwah, dan berbagai kegiatan sosial lain yang diinisiasi oleh ICM, disamping banyak pula diantaranya yang menyekolahkan ana-anak mereka di lembaga pendidikan keagamaan ini.

Bangkitnya religiusitas dalam masyarakat modern disebabkan salah satunya oleh karena masyarakat merasa tidak cukup puas dengan institusi keagamaan formal yang selama ini sudah ada karena dianggap tidak mampu menjawab kebutuhan-kebutuhan spiritual masyarakat. Disamping itu, bangkitnya kesadaran beragama masyarakat juga disebabkan oleh rasa jenuh, prihatin, dan rasa gamang masyarakat dalam menghadapi dampak-dampak modernisasi yang bersifat negatif, seperti menurunnya moralitas dan etika sosial, kesenjangan sosial yang semakin jelas, meningkatnya individualitas dan kontrol sosial yang semakin longgar.

Kehadiran institusi keagamaan dianggap sebagai jawaban atas kegamangan masyarakat atas persoalan-persoalan hidup yang ternyata sulit dipecahkan dan diatasi oleh negara. Dalam kondisi demikian, manusia mengalami kondisi yang disebut dengan alienasi atau perasaan terasing di tengah-tengah keramaian. Fromm menegaskan bahwa manusia telah mengarahkan pemikirannya pada berhala-berhala yang diciptakan oleh media massa dan pendapat umum, pemerintah, atau para pimpinan politik. Mereka telah memilih hal-hal tersebut sebagai berhala sesembahannya, tuhan-tuhan yang memberikan kebajikan dan pengetahuan. Manusia telah bergantung pada berhala-berhala yang sebenarnya tidak mampu menerima pengabdian dan penyembahan yang mereka lakukan..$^{28}$ Alienasi dialami manusia ketika ia mengabaikan dan meminggirkan eksistensi dan peran Tuhan.

Dalam konteks demikian, masyarakat perkotaan menemukan dan memapankan relgiusitasnya justru dalam dunia modern atau yang disebut sebagai urban piety. ${ }^{29}$ Penelitian Sakai membuktikan bahwa modernitas nyatanya justru menguatkan kesalehan bagi banyak orang. ${ }^{30}$ Demikian pula studi yang dilakukan Hasbullah yang menegaskan bahwa bangkitnya kelompok-kelompok dan organisasi-organisasi keagamaan di Indonesia yang mulai muncul sejak tahun 1980-an adalah bukti bangkit dan menguatnya

${ }^{28}$ Fromm, Erich, The Sane Society, (New York: Holt, Reinehart and Winston, 1971), 55.

${ }^{29}$ Lihat penelitian Zamhari, Arif\&Howell, Julia Day, "Taking Sufism to the Streets; Majelis Zikir and Majelis Shalawat as New Venue for Popular Islamic Piety in Indonesia". Review of Indonesia and Malasyian Affairs, Vol. 46, No. 2, (2012): 47-75.

${ }^{30}$ Sakai, Minako, "Ethical Self-Improvement in Everyday Life: Propagating the Islamic Way of Life in Globalised Indonesia", Dipresentasikan Dalam $18^{\text {th }}$ Biennial Conference of the Asian Studies Association of Australia di Adelaide, 5-8 July 2010. 
keberagamaan kaum kelas menegah perkotaan. Hal ini justru menunjukan kelemahan dari upaya sekularisasi yang banyak digaungkan oleh para pakar ilmu sosial ${ }^{31}$. Modernitas tidak lantas mematikan kesadaran masyarakat tentang agama. Modernisasi justru menumbuhsuburkanya dalam bentuk yang lain. Kebangkitan Islam di Indonesia mengindikasikan bagaimana modernitas dan Islam bisa berjalan seiring. Modernitas tidak selalu berarti menghancurkan agama sebagaimana yang didengun-dengungkan oleh teori sekularisasi. Kebangkitan kesadaran beragama memberi peluang bagi sumber-sumber peradaban Islam meneguhkan pengaruh dan otoritasnya.

\section{E. PENUTUP}

Lembaga Islamic Centre Mu'adz bin Jabal Kota Kendari adalah lembaga yang merujuk pada gagasan Islamic Centre yang dimaksudkan sebagai pusat kegiatan umat Islam yang merangkul semua kelompok masyarakat tanpa dibatasi oleh sekat-sekat paham. Pendirian lembaga ini diilhami oleh pendirian Islamic Culture Centre (ICC) di Damam Arab Saudi, tempat Ustadz Zezen Zainal Mursalin, Lc dulu bekerja. Program kerja ICM difokuskan pada pendidikan, dakwah, kegiatan sosial, dan pelayanan umat lainnya. Meskipun bernama Islamic Centre, lembaga ini menggunakan kurikulum Pendidikan dan Kebudayaan, bukan kurikulum Kementerian Agama, dengan menfokuskan pada program unggulan berupa hafalan $\mathrm{Al}$ Qur'an pada semua jenjang pendidikan, mulai dari TK hingga SMA dan Program Kaderisasi Imam dan Da'i. Lembaga ini mengalami progresivitas pembangunan infrastruktur yang relatif cepat dibandingkan dengan lembaga pendidikan dan dakwah Islam lainnya di Kota Kendari. Lembaga ini juga direspon oleh masyarakat dengan menjadi pengurus atau jama'ah aktif dari kalangan ekonomi dan pendidikan relatif tinggi dengan beragam profesi.

\section{Daftar Pustaka}

Anjum, Ovamir. "Islam as a Discursive Tradition; Talal Asad and His Interlocutors". Comparative Studies of South Asia, Africa, and The Midlle East. Vol. 27, No. 3, (2007): 656-672.

Asad, Talal. The Idea of an Anthropology of Islam. Occasional Paper Series.

Center for Contemporary Arab Studies. Georgetown University, Washington D.C. 1986.

Bowen, John Robert. Muslim through Discourse; Religion and Ritual in Gayo Society. United Kingdom: Princenton University Press. 1993.

${ }^{31}$ Hasbullah, Moeflich, "Cultural Presentation of the Muslim Middle Class in Contemporary Indonesia”, Jurnal Studia Islamika, VoL 7, No. 2, (2000): 1-58. 
Budiwanti, Erni. Islam Sasak; Wetu Telu versus Wektu Lima. Yogyakarta: LkiS. 2000.

Campbell, Heidi A \& Paul Emerson Teusner, Religious Authority in the Age of the Internet, (Center for Christian Ethics: Baylor University, 2011).

Djamhari, Arif \& Julia Day Howell. "Taking Sufism to the Streets; Majelis Zikir and Majelis Shalawat as New Venue for Popular Islamic Piety in Indonesia”. Review of Indonesia and Malasyian Affairs. Vol. 46, No. 2, (2012): 47-75.

Ekomadyo, Agus S, "Kajian Relasi Sosio-Spasial Antara Masjid Dan Pasar: Kajian Atas Kontribusi Islam Dalam Urbanitas Kontemporer", Seminar Nasional Arsitektur islam 2, Universitas Muhammadiyah Surakarta, 2012.

Farihah, Irzum. "Media Dakwah Pop". AT-TABSYIR; Jurnal Komunikasi Penyiaran Islam. Vol. 1, No 2, (Juli-Desember, 2013): 25-45.

Fromm, Erich, The Sane Society. New York: Holt, Reinehart and Winston. 1971.

Hamdi, Ahmad Zainul, "Agama di Tengah Jaring-Jaring Dunia Modern", Jurnal Religió: Jurnal Studi Agama-Agama, Vol. 3, No. 2, (September, 2013): 187-208.

Hasbullah, Moeflich, "Cultural Presentation of the Muslim Middle Class in Contemporary Indonesia", Jurnal Studia Islamika, VoL 7, No. 2, (2000): 1-58.

Hasan, Noorhaidi, Laskar Jihad: Islam, militansi, dan Pencarian Identitas di Indonesia Pasca Orde Baru, (Jakarta: LP3ES \& KITLV-Jakarta, 2008)

Hassan, Rifaat. "On Being Religious: Patterns of Religious Commitment in Muslim Societies". Faithlines: Muslim Conception of Islam and Society. USA: Oxford University Press. 2003.

Haqqani, Shehnaz, Muslim Televangelists and the Construction of Religious Authority in the Modern World: The Case of Zakir Naik, Tesis di Faculty of Emory College of Arts and Sciences of Emory University, Department of Middle Eastern and South Asian Studies, 2011.

Heryanto, Ariel. "Kelas Menengah yang Majemuk", dalam Hadi Jaya, Kelas Menengah Bukan Ratu Adil.Yogyakarta: Tiara Wacana, 1994.

Naisbitt, John \& Patricia Aburdene. Megatrend 2000. New York: William Morrow \& Company. 1990.

Saefulloh, Aris. "Dakwahtainment: Komodifikasi Industri Media Di Balik Ayat Tuhan". Komunika; Jurnal Dakwah dan Komunikasi, Vol.3 No. 2, (Juli-Desember, 2009): 255-266.

Sakai, Minako. "Ethical Self-Improvement in Everyday Life: Propagating the Islamic Way of Life in Globalised Indonesia", Dipresentasikan Dalam 
18th Biennial Conference of the Asian Studies Association of Australia di Adelaide, 2010. 5-8 July.

Zulkifli. "The Ulama in Indonesia; between Religious Authority and Symbolic Power". Jurnal Miqot, Vol. 37, No. 1, (Januari-Juni, 2013): 180-197.

Website;

http://www.icm.or.id. Diakses pada tanggal 6 September 2016 